\title{
Diversity and habitat preference of medium and large-sized mammals in an urban forest fragment of southwestern Amazon
}

\author{
Luiz H. M. Borges², Armando. M. Calouro², André L. M. Botelho ${ }^{1} \&$ Marcos Silveira² $^{2}$
}

1. Programa de Pós-Graduação em Ecologia e Manejo dos Recursos Naturais, Universidade Federal do Acre, Campus Universitário, BR-364, Km 04 - Distrito Industrial, Caixa Postal 500,
69920-900 Rio Branco, AC, Brazil. (Corresponding author: borges.lhm@gmail.com)
2. Centro de Ciências Biológicas e da Natureza, Universidade Federal do Acre, Campus Universitário, BR-364, Km 04 - Distrito Industrial, Caixa Postal 500, $69920-900$ Rio Branco, AC, Brazil.

\begin{abstract}
We assessed the species composition and abundance of medium and large-sized mammals in an urban forest fragment in the Brazilian Amazon, and recorded the preference of some species for particular phytophysiognomies. We placed nine transects with 20 sand plots each in three phytophysiognomies: open rainforest with a dominance of bamboos (OFB), open rainforest with palm trees (OFP), and dense rainforest (DF). We calculated species abundance as the number of records/plot.day, in a total of 2,700 plots.day. We recorded twelve mammal species; Sylvilagus brasiliensis (Linnaeus, 1758) and Dasyprocta fuliginosa (Wagler, 1831) were the most abundant. The results differed among phytophysiognomies: DF presented the highest mammal diversity, whereas the species composition of OFP was less similar than that of other phytophysiognomies. Rodents showed higher preference for OFP and Sylvilagus brasiliensis was more abundant in OFB. The study area showed high species richness, with the occurrence of mesopredators, but there was a predominance of common species adaptable to disturbed environments, which reflects the severe isolation degree of the forest fragment and the hunting pressure that is still present.
\end{abstract}

KEYWORDS. Acre, sand plot, rodents, 'tapiti', palm tree.

RESUMO. Diversidade e preferência de habitat de uma comunidade de mamíferos de medio e grande porte num fragmento florestal urbano na Amazônia Sul-Ocidental. Nós avaliamos a composição e abundância de mamíferos de médio e grande porte em um fragmento florestal urbano na Amazônia brasileira, além de registrar a preferência de habitat de algumas espécies a determinadas fitofisionomias. Nove transectos com 20 parcelas de areia cada foram dispostas de forma igualitária em três fitofisionomias: Floresta Ombrófila Aberta com Bambu Dominante (FAB), Floresta Ombrófila Aberta com Palmeira (FAP) e Floresta Ombrófila Densa (FD). A abundância das espécies foi obtida pelo numero de registros da espécie/parcelas.dia, totalizando 2700 parcelas.dia. Doze espécies de mamíferos foram registradas, sendo Sylvilagus brasiliensis (Linnaeus, 1758) e Dasyprocta fuliginosa (Wagler, 1831) as mais abundantes. Nossos resultados apresentaram diferenciação em termos de espécies para as fitofisionomias: a FD apresentou maior diversidade de mamíferos, enquanto a composição de espécies da FAP apresentou maior dissimilaridade com relação às demais. Os roedores tiveram maior preferência pela FAP e Sylvilagus brasiliensis apresentou maior abundância na FAB. A área apresentou riqueza de espécies relevante, com a ocorrência de mesopredadores, mas há o predomínio de espécies comuns e adaptáveis a ambientes perturbados, refletindo o acentuado grau de isolamento do fragmento florestal e a pressão de caça ainda existente.

PALAVRAS-CHAVE. Acre, parcela de areia, roedores, tapiti, palmeira.

Among the 5,487 extant mammal species in the world (SCHIPPER et al., 2008), ca. 12.8\% occur in Brazil, and 399 species are found in the Amazon (PAgLia et al., 2012). Western Amazon, where the state of Acre is located, is one of the regions with highest species richness (SCHIPPER et al., 2008). However, although $86.87 \%$ of its territory is still covered by forests (INPE, 2010), the east of Acre is under an accelerated forest fragmentation process (ACRE, 2006). Population decrease or the local extinction of mammals caused by fragmentation and other human effects has a very negative effect on the maintenance of biodiversity as a whole, since Neotropical mammals have an important function in the recruiting of plant species (Peres \& Palacios, 2007; Wright et al., 2007) and in the regulation of forest ecosystems (TERBORGH et al., 2001).

Edge effects caused by forest fragmentation in tropical forests tend to reduce biological diversity, as shown by long-term studies carried out in the Amazon (LAURANCE et al., 2011). Combined with genetic isolation and area reduction, these effects cause a negative synergy on the populations of medium and large-sized mammals, with the local extinction of several species. In addition, fragmentation tends to facilitate the access to the area for hunters, who aim at large-bodied species (Peres, 2001). Nevertheless, forest fragments are increasingly seen as important components of human-modified landscapes and should be considered in strategies for partial recovery of biodiversity in altered areas (TURNER \& CORLETT, 1996).

Terrestrial medium and large-sized mammals of Neotropical forests are rarely assessed in ecological studies due to their low local abundance and nocturnal habits, together with the large size of their home ranges (Voss \& EMmons, 1996). These factors hinder the conduction of studies aimed at the composition, structure, and dynamics of these communities. According to Scoss et al. (2004), indirect indicators of mammals are cheaper, faster, and easier to use in the field than direct methods (observation and capture). The identification and counting of tracks have been used as an index of relative abundance, especially for species difficult to visualize (Cú́lLAR \& Noss, 1997; Stander, 1997; Simonetti \& Huereco, 1999), well as the diversity index, as done by Rocha \& Dalponte (2006) and Norris \& Peres (2008). So sand plots distributed in transects inside the forest to record mammal tracks proved 
to be efficient for nocturnal and cryptic species (Scoss et al. 2004; PARDINI et al. 2006), but this method was seldom used in the Brazilian Amazon (Norris \& Peres, 2008).

The few studies on the community of medium and large mammals carried out so far in the state of Acre have focused on rapid inventories (CALOURO, 1999; BotelHo et al., 2012), effects of hunting on mammals (CALOuRo \& Marinho-Filho, 2005; Rosas \& Drumond, 2007; Constantino et al., 2008), and autecology of primates (Bicca-Marques \& Garber, 2003; Regh, 2006).

The objective of the present study was to describe the composition and relative abundance of medium and large mammals in an urban forest fragment in Rio Branco, state of Acre, northern Brazil, known as Parque Zoobotânico (PZ). We also discuss the differences in relative abundance among three phytophysiognomies of the forest fragment, as well as habitat preferences of some species.

\section{MATERIAL AND METHODS}

Study area. Parque Zoobotânico (PZ) is an urban forest fragment with 165 ha (Fig. 1), located in the city of Rio Branco, state of Acre, northern Brazil, within the campus of Universidade Federal do Acre (9 $57^{\circ} 26^{\prime \prime}$ 'S, $\left.67^{\circ} 52^{\prime} 25^{\prime \prime} \mathrm{W}\right)$. According to meteorological data provided by INMET (2012), during the study period (August 2009 to October 2010) the average temperature was $26.6{ }^{\circ} \mathrm{C}$ (minimum of $9.9^{\circ} \mathrm{C}$ and maximum of $38.9^{\circ} \mathrm{C}$ ) and the accumulated rainfall was $2,308.4 \mathrm{~mm}$. July 2010 was the driest month $(0.6 \mathrm{~mm})$ and December 2009 was the rainiest $(377.1 \mathrm{~mm}) . \mathrm{PZ}$ is located within a landscape, whose matrix is formed by houses and pastures; therefore, it is subjected to a sporadic hunting pressure by the local inhabitants. The vegetation of $\mathrm{PZ}$ is composed of mature riparian forest, at a smaller scale, and predominantly by second-growth vegetation at different successional stages (MENESES FiLHO et al., 1995), and it is characterized either by palm stipes or by bamboos (Guadua weberbaueri Pilger) culms of a native scandent species typical of open forests with bamboo found in Acre. This bamboo species is characterized by opportunistic growth with fast aerial development of culms in clearings (SiLveira, 2005).

Vegetation. In order to assess the differences among vegetation types (phytophysiognomies), we delimited a 4 x 250-m plot in each of the nine transects used in the study, in which we sampled stems with diameter at breast height (DBH) above $10 \mathrm{~cm}$. Within each plot, we delimited a $2 \mathrm{x}$ 250-m subplot to sample stems with DBH between 5 and $10 \mathrm{~cm}$. In both sampling systems the stems were classified as trunk (TRU), stipe (STI), and culm (CUL). We used the predominance of stem types to distinguish between phytophysiognomies.
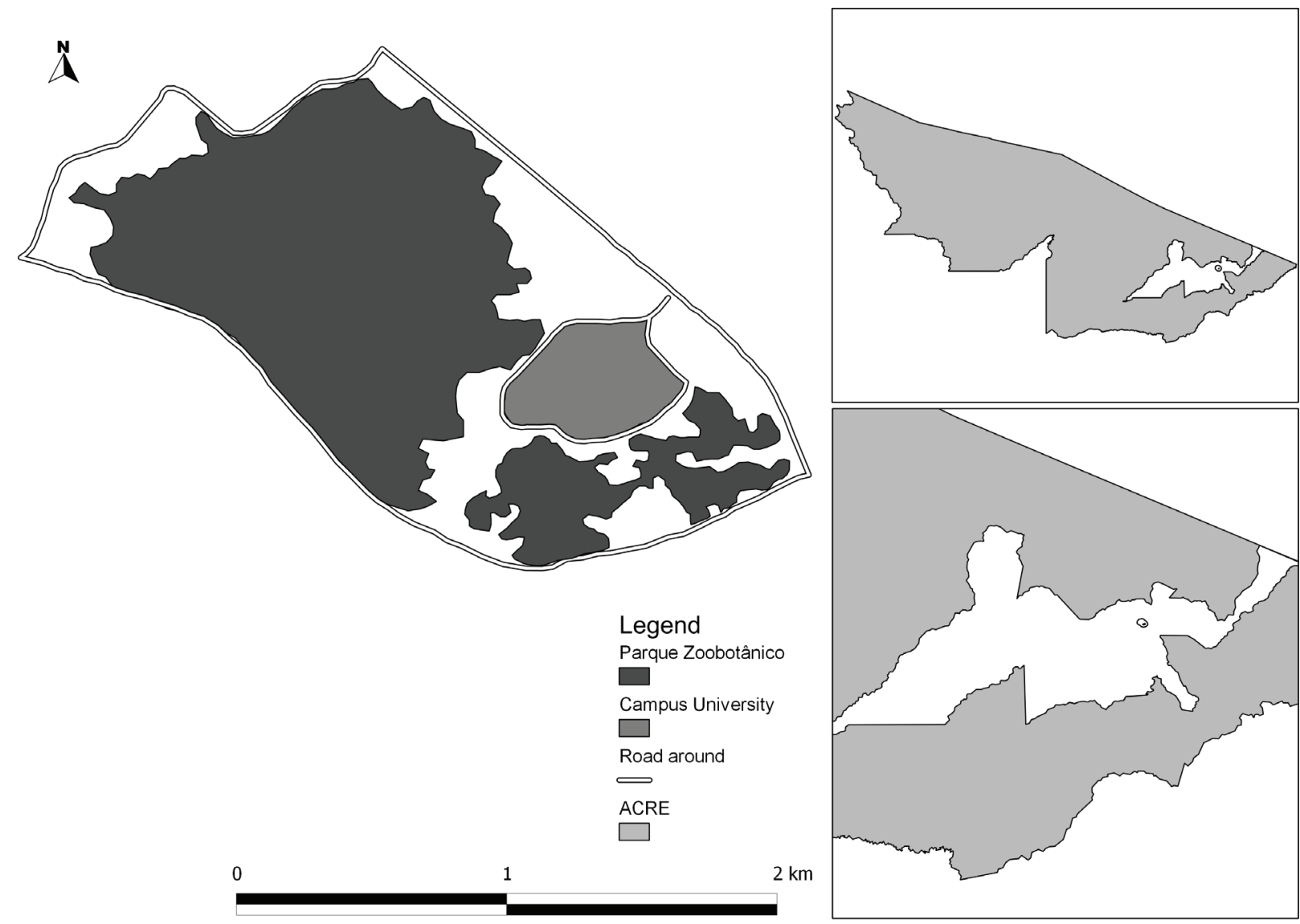

Fig. 1. Location of Parque Zoobotânico in the urban area of Rio Branco, state of Acre, northern Brazil. 
Mammals. We distributed 60 sand plots evenly in three phytophysiognomies of PZ: open rainforest with a dominance of bamboo (OFB), open rainforest with palm trees (OFP), and dense rainforest (DF). In each phytophysiognomy we used three transects with 20 sand plots each $(0.5 \times 0.5 \mathrm{~m}$ and $2 \mathrm{~cm}$ in height), placed at 10 $\mathrm{m}$ from each other. Each transect was sampled for 15 days and installed at a minimum distance of $100 \mathrm{~m}$ from the next transect, following PARDINI et al. (2006).

We recorded the presence of tracks every $24 \mathrm{~h}$, in each plot was considered only a single record per species, to avoid overestimated, and then cleaned the plots (by removing leaves and twigs), moistened, and provided them sequentially with banana and bacon baits. The plots with baits were interpolated with plots with no baits, as individuals or species may respond differently to the baits, and the presence of one species may influence the presence of others (CuTLER \& SwANn, 1999). The tracks were photographed (with scale) and identified using field guides (Becker \& Dalponte, 1991; Borges \& Tomás, 2004; Carvalho \& Luz, 2008; Mamede \& Alho, 2008).

Data analysis. The relative abundance of each species considering the sampling effort was calculated as follows: the number of individual sequences of tracks of each species was divided by the total number of plots exposed multiplied by total number of the days sampled in each phytophysiognomy (number of records of the species/plot.day).

We used an analysis of variance to test for differences in the dominant tree component of each phytophysiognomy (trunks, stipes, and culms), and made de calculations in STATISTICA 7.0 (StATsOFt, 2004). We calculated Margalef richness (d) and Shannon diversity (H', calculated with the natural logarithm) for each phytophysiognomy in the program PAST 2.0 (HAMMER et al., 2001), as well as the Hutcherson $t$ diversity test, in order to compare the diversity between environments. We also calculated the Bray-Curtys similarity. All analysis followed LuDwIG \& REYNOLDS (1988).

\section{RESULTS}

Characterization of forest phytophysiognomies. In 0.72 ha, considering the three phytophysiognomies studied, we sampled 1,345 stems: 689 culms, 520 trunks, and 136 stipes. The abundance of trunks was significantly higher in DF than in the other areas $\left(\mathrm{F}_{\mathrm{ANOVA}}=21.56\right.$; d.f. $=2: 6 ; \mathrm{p}=$ 0.002; Post Hoc Tukey p-value: DF - OFP $=0.005$, DF $\mathrm{OFB}=0.002$, and $\mathrm{OFP}-\mathrm{OFB}=0.713$ ). The abundance of stipes was higher in OFP than in DF and OFB $\left(\mathrm{F}_{\mathrm{ANOVA}} 10.8\right.$; d.f. $=2: 6 ; \mathrm{p}=0.011$; Post Hoc Tukey $\mathrm{p}$-value: $\mathrm{DF}-\mathrm{OFP}=$ $0.03 ; \mathrm{DF}-\mathrm{OFB}=0.66 ; \mathrm{OFP}-\mathrm{OFB}=0.01$ ). The number of culms was significantly higher in $\mathrm{OFB}\left(\mathrm{F}_{\mathrm{ANOVA}}=61.59\right.$; d.f. $=2: 6 ; \mathrm{p}<0.001$; Post Hoc Tukey $\mathrm{p}$-value: $\mathrm{DF}-\mathrm{OFP}=$ 0.943; DF - OFB <0.001; OFP - OFB < 0.001) (Fig. 2).

Species richness, diversity, and habitat preferences. From August 2009 to October 2010 we made a sampling effort of 2,700 plots.day, equally distributed among phytophysiognomies, and obtained 147 records of 12 mammal species (Tab. I).

The species with highest relative abundances were Sylvilagus brasiliensis (more abundant in OFB) and Dasyprocta fuliginosa (more abundant in OFP). Of seven primate species present in $\mathrm{PZ}$, at least two were recorded with sand plots and were attracted to banana baits. Unfortunately, it was not possible to identify Saguinus to the species based only on tracks, but in PZ there are only two species: Saguinus imperator and Saguinus weddelli. The sand plot method is not suitable to estimate primate abundance, and the method of direct observations on trails is advised (NRC, 1981).

The most diverse phytophysiognomy in terms of

Tab. I. Relative abundance of mammals in Parque Zoobotânico (PZ), urban area of Rio Branco, state of Acre, northern Brazil (OFB, open forest with bamboo; OFP, open forest with palm tree; DF, dense forest; Ab, relative abundance - number of records of each species/plot/night; the number of records is in parentheses; species conservation status according to IUCN: LC, least concern).

\begin{tabular}{|c|c|c|c|c|c|c|}
\hline \multirow{2}{*}{ Order } & \multirow{2}{*}{ Species } & \multirow{2}{*}{ Common name } & OFB & OFP & DF & Status \\
\hline & & & $\mathrm{Ab}$ & $\mathrm{Ab}$ & $\mathrm{Ab}$ & IUCN \\
\hline \multirow[t]{3}{*}{ Carnivora } & Leopardus pardalis (Linnaeus, 1758) & Ocelot & $0.012(6)$ & $0.006(3)$ & 0 & LC \\
\hline & Eira barbara (Linnaeus, 1758) & Tayra & $0.006(3)$ & 0 & $0.004(2)$ & LC \\
\hline & Galictis vittata (Linnaeus, 1758) & Greater Grison & 0 & $0.002(1)$ & $0.002(1)$ & LC \\
\hline Lagomorpha & Sylvilagus brasiliensis (Linnaeus, 1758) & Tapeti & $0.084(42)$ & $0.0012(6)$ & $0.012(6)$ & LC \\
\hline \multirow[t]{2}{*}{ Primates } & Callicebus cupreus (Spix, 1823) & Red titi monkeys & $0.002(1)$ & 0 & $0.004(2)$ & LC \\
\hline & Saguinus sp. & Weddell's Saddle-back Tamarin & $0.022(11)$ & $0.006(3)$ & $0.008(4)$ & LC \\
\hline \multirow[t]{4}{*}{ Rodentia } & Coendou prehensillis (Linnaeus, 1758) & Brazilian Porcupine & 0 & $0.01(5)$ & 0 & LC \\
\hline & Hydrochoeris hydrochaeris (Linnaeus, 1762) & Capybara & $0.012(6)$ & $0.004(2)$ & $0.006(3)$ & LC \\
\hline & Cuniculus paca (Linnaeus, 1776) & Spotted Paca & 0 & $0.002(1)$ & 0 & LC \\
\hline & Dasyprocta fuliginosa (Wagler, 1831) & Black Agouti & $0.002(1)$ & $0.062(31)$ & $0.002(1)$ & LC \\
\hline Pilosa & Tamandua tetradactyla (Linnaeus, 1758) & Southern Tamandua & $0.004(2)$ & 0 & $0.002(1)$ & LC \\
\hline Cingulata & Dasypus novemcinctus Linnaeus, 1758 & Nine-banded Armadillo & $0.004(2)$ & 0 & $0.002(1)$ & LC \\
\hline
\end{tabular}




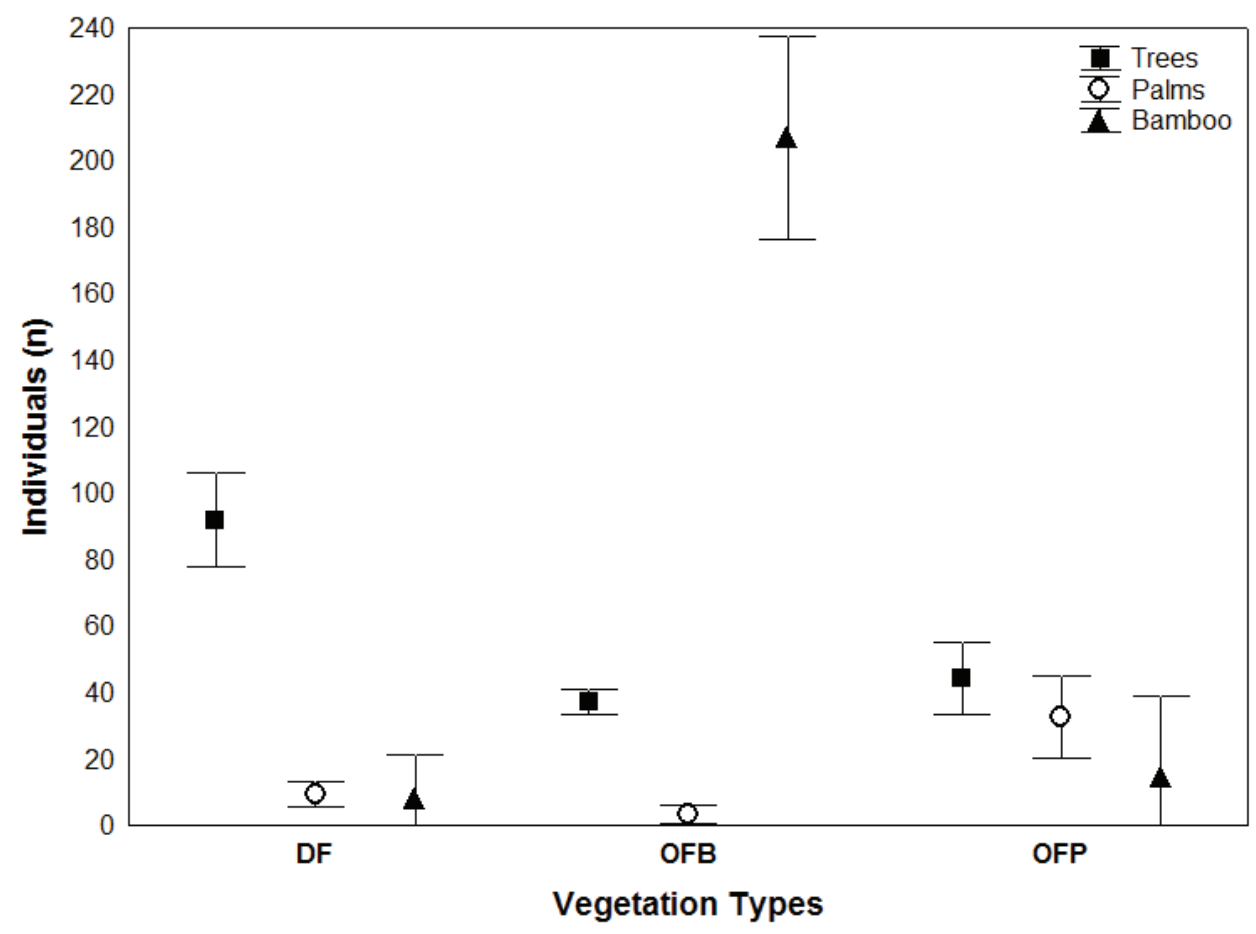

Fig. 2. Average number of trees (DBH $>10 \mathrm{~cm}, \boldsymbol{\square})$ palm trees (stipes higher than $1 \mathrm{~m}, \bullet$ ), and bamboo culms $(\boldsymbol{\Delta})$ and standard deviations in three phytophysiognomies.



Fig. 3. Use of different habitats (\%) by medium and large mammals in Parque Zoobotânico (PZ), urban area of Rio Branco, state of Acre, northern Brazil (OFB, open forest with bamboo; OFP, open forest with palm tree; DF, dense forest). 
mammals was $\mathrm{DF}\left(\mathrm{d}=2.628, \mathrm{H}^{\prime}=1.98\right)$, followed by OFB $\left(\mathrm{d}=1.859, \mathrm{H}^{\prime}=1.454\right)$, and OFP $\left(\mathrm{d}=1.772, \mathrm{H}^{\prime}=1.389\right)$. We observed a significant difference in species diversity between OFP and DF ( $p=0.049)$, but not between OFP and OFB $(p=0.708)$, and between OFB and DF $(p=0.077)$. In terms of similarity in mammal species composition, the community of OFP was the least similar to the other phytophysiognomies $(\mathrm{OFP}-\mathrm{OFB}=23.81$; OFP-DF $=35.62)$; the mammal communities of physiognomies without the predominance of palm trees were more similar to each other $(\mathrm{OFB}-\mathrm{DF}=40)$.

The phytophysiognomy with highest number of records was OFB $(n=74)$, followed by OFP $(n=52)$, and $\mathrm{DF}(\mathrm{n}=21)$. Of the six orders of medium and large-sized mammals recorded in the present study only two showed preferences for a particular plant physiognomy. As shown in Fig. 3, there is a strong association of rodents with the OFP $(\mathrm{n}=39)$, and of the lagomorph S. brasiliensis with the OFB $(n=42)$.

\section{DISCUSSION}

Agouti was one of the most abundant species (Tab. I), which is consistent with NorRIS \& Peres (2008), who used sand plots in forest fragments in the state of Amazonas. The relatively high abundance of agoutis is related to the high reproductive success of this group and to its capacity of consuming a broad variety of fruits (HenRY, 1999). On the contrary, the spotted paca (Cuniculus paca) had relatively low abundance, in spite of, likewise the agouti, presenting a relatively high reproductive success for a medium mammal (Robinson \& RedFord, 1986). Chiarello (2000), in a study carried out in Atlantic Forest fragments, pointed out that both species may go extinct in fragments exposed to constant hunting pressure.

The high abundance of $S$. brasiliensis in OFB may be explained by the high adaptive plasticity of this species, which has broad geographic distribution and is able to use different habitat types, including forests with dense understory and edges (EINSEBERG \& REDFORD, 1999). The dense and impenetrable understory created by the weave of bamboo culms provides a favorable habitat for S. brasiliensis. Hence, the distribution of this species is influenced by the bamboo patches found in PZ.

The mammal species composition found in OFP had low similarity to the other phytophysiognomies, due to a higher density of palm trees present in OFP. This probably leads to a higher occurrence of rodent species, with a larger number of records of agouti tracks. This difference is associated with the preference of rodents for palm fruits. Rodents are considered the largest mammal group that consumes palm fruits in the tropics (ANDREAZZI et al., 2009). Some palm species that occur in PZ, such as Socratea exorrhiza (Mart.) H. Wendl. (walking palm, locally known as paxiubinha), Iriartea deltoidea Ruiz \& Pavon (locally known as paxiubão), Attalea phalerata Mart. ex Spreng. (ouricuri palm), Attalea butyracea (Mutis ex L.f.) Wess.
Boer (jaci palm), Astrocaryum aculeatum G. Mey. (locally known as tucumã), and Astrocaryum ulei Burret (locally known as murmuru), are part of the diet of the rodents recorded in OFP (ANDREAZZI et al., 2009). According to Dirzo et al. (2007), species of the family Arecaceae have been pointed out as the most susceptible to the disruption of their interactions with animals, as they are dispersed or predated by a small number of frugivores, many of which are hunted (Peres, 2000; Galetti et al., 2006).

In general, the study area had a high species richness, considering the deleterious effects of forest fragmentation, such as edge effects, genetic isolation, and high accessibility to hunters (Vianna \& Pinheiro ,1998; Gascon et al., 2000; Peres, 2001; Peres \& Lake, 2003). The difference observed in mammal species composition among physiognomies emphasizes the importance of heterogeneous environments for the maintenance of wild populations, mainly of mammals, by providing different habitats necessary to supply their needs. We also highlight the presence of mesopredators, such as Leopardus pardalis and Eira barbara, which play an important role in the maintenance of prey diversity, by controlling their populations and inhibiting the predominance of competitively superior species (FONSECA \& ROBINSON, 1990; Wright et al., 1994). Hence, according to TURNER \& CORLETT (1996), small fragments are important for conserving the biodiversity of altered sites. Table I lists a set of species considered common, unthreatened, and adaptable to disturbed habitats, reflecting the impacts of fragmentation and hunting pressure. There is a need for monitoring the mammal fauna of the park, in order to assess its integrity and maintain the local fauna in the long term. Due to the size and isolation of PZ, its populations of mesopredators are relatively small (as reflected in their low abundance) and will become unviable in the long term. Management of mesopredator populations in the area is needed, since these species are essential for the balance of the local mammal fauna.

Acknowledgements. We thank the Superintendência da Zona Franca de Manaus (SUFRAMA) for the financial support, especially Dr. Lisandro Juno Soares Vieira (local coordinator of the project during the present study), the Conselho Nacional de Desenvolvimento Científico e Tecnológico (CNPq), and the board of Parque Zoobotânico of UFAC for permitting the study in the area. We also thank Richarlly da Costa Silva for the invaluable help in the. We also thank the people who helped us in other phases of the study.

\section{REFERENCES}

ACRE. 2006. Zoneamento Ecológico-Econômico do Acre Fase II: Documento Síntese-Escala 1:250.000. Rio Branco, SEMA. 354p. Andreazzi, C. S.; Pires, A. S. \& Fernandez, F. A. S. 2009. Mamíferos e palmeiras neotropicais: Interações em paisagens fragmentadas. Oecologia Brasiliensis 13(4):554-574

Becker, M. \& Dalponte, J. C. 1991. Rastros de Mamíferos Silvestres Brasileiros - Um Guia de Campo. Brasília, Editora UnB. 180p.

Bicca-Marques, J. C. \& Garber, P. A. 2003. Experimental field study of the relative costs and benefits to wild tamarins (Saguinus imperator and Saguinus Fuscicollis) of exploiting contestable food patches as single- and mixed-species troops. American Journal of Primatology 60:139-153. 
Borges, P. A. L. \& Tomás, W. M. 2004. Guia de Rastros e Outros Vestígios de Mamíferos do Pantanal. Corumbá, Embrapa Pantanal. 139 p.

Botelho, A. L. M; Calouro, A. M.; Borges, L. H. M. \& Chaves, W. A. 2012. Large and medium-sized mammals of the Humaitá Forest Reserve, southwestern Amazonia, state of Acre, Brazil. Check List 8(6):1190-1195.

Carvalho, O. J. \& Luz, N. C. 2008. Pegadas: Série Boas Práticas Livro 3. Belém, Editora Universitária UFPA. 64p.

Calouro, A. M. 1999. Riqueza de mamíferos de grande e médio porte do parque nacional da Serra do Divisor (Acre, Brasil). Revista Brasileira de Zoologia 16(2):195-213.

Calouro, A. M. \& Marinho-Filho, J. S. 2005. A caça e pesca de subsistência entre seringueiros ribeirinhos e não-ribeirinhos da Floresta Estadual do Antimary (AC). In: Drumond, P. ed. Fauna do Acre. Rio Branco, Editora da Universidade Federal do Acre. p.109-135.

Chiarello, A. G. 2000. Density and population size of mammals in remnants of Brazilian Atlantic Forest. Conservation Biology 14(6):1649-1657.

Constantino, P. A. L.; Fortini, L. B.; Kaxinawa, F. R. S.; Kaxinawa, A. M.; Kaxinawa, E. S.; Kaxinawa, A. P.; Kaxinawa, L. S.; Kaxinawa, J. M. \& KaXinAwA, J. P. 2008. Indigenous collaborative research for wildlife management in Amazonia: The case of the Kaxinawá, Acre, Brazil. Biological Conservation 141:2718-2729.

Cuéllar, E. \& Noss, A. 1997. Conteo de huellas en brechas barridas: un índice de abundancia para mamíferos. Ecologia en Bolivia 30:55-67.

Cutler, T. L. \& Swann, D. E. 1999. Using remote photography in wildlife ecology: a review. Wildlife Society Bulletin 27(3):571-581.

Dirzo, R.; Mendonza, E. \& Ortiz , P. 2007. Size-related differential seed predation in a heavily defaunated Neotropical rain forest. Biotropica 39(3):355-362.

Eisenberg, J. F. \& Redford, K. H. 1999. Mammals of the Neotropics: The Central Neotropics. Ecuador, Peru, Bolivia, Brazil. v 3. Chicago, The University of Chicago Press. 609p.

Fonseca, G. A. B. \& Robinson, J. G. 1990. Forest size and structure: competitive and predatory effects on small mammal communities. Biological Conservation 53(4):265-294.

Galetti, M.; Donatti, C. I.; Pires, A. S.; Guimarães, P. R. \& Jordano, P. 2006. Seed survival and dispersal of an endemic Atlantic forest palm: the combined effects of defaunation and fragmentation. Botanical Journal of the Linnean Society 151(1):141-149.

Gascon, C.; Williamson, G. B. \& Fonseca, G. A. B. 2000. Receding forest edges and vanishing reserves. Science 288:1356-1358.

Hammer, Ø.; Harper, D. A. T. \& Ryan, P. D. 2001. PAST: Paleontological statistics software package for education and data analysis. Paleontologia Electronica 4(1):1-9.

Henry, O. 1999. Frugivory and the importance of seeds in the diet of the orange-rumped agouti (Dasyprocta leporina) in French Guiana. Journal of Tropical Ecology 15(3):291-300.

INMET - Instituto Nacional de Meteorologia. 2012. Banco de Dados Meteorológicos para Ensino e Pesquisa. Available at $<\mathrm{http}$ :// www.inmet.gov.br/portal/index.php?r=bdmep/bdmep $>$. Accessed on 28 June 2012.

INPE - Instituto Nacional de Pesquisas Espaciais. 2010. Estimativas Anuais das Taxas de Desmatamento na Amazônia Geradas pelo Relatório do Projeto PRODES. Available at $<$ http://www.obt.inpe. br/prodes/prodes_1988_2009.htm >. Accessed on 25 November 2010.

Laurance, W. F.; Camargo, J. L. C.; Luizão, R. C. C.; Laurance, S. G.; Pimm, S. L.; Bruna, E. M.; Stouffer, P. C.; Williamson, G. B.; Benítez-Malvido, J.; Vasconcelos, H. L.; Van Houtan, K. S.; Zartman, C. E.; Boyle, S. A.; Didham, R. K.; Andrade, A. \& Lovejoy, T. H. 2011. The fate of Amazonian forest fragments: a 32year investigation. Conservation Biology 144(1):56-67.

Ludwig, J. A. \& Reynolds, J. F. 1988. Statistical Ecology. New York, Wiley Interscience Publications. 337p.

Mamede, S. B. \& Alho, O. C. J. 2008. Impressões do Cerrado \& Pantanal: Subsídios para a Conservação de Mamíferos Silvestres Não-Voadores. Campo Grande, Editora da Universidade Federal do Mato Grosso do Sul. 208p.
Meneses Filho, L. L. C; Ferraz, P. A.; Pinha, L. A. \& Brilhante, N. A. 1995. Comportamento de 24 Espécies Arbóreas Tropicais Madeireiras Introduzidas no Parque Zoobotânico, Rio BrancoAcre. v. I. Rio Branco, Editora da Universidade Federal do Acre. 135p.

Norris, D. \& Peres, C. A. 2008. Terrestrial mammal responses to edges in Amazonian forest patches: a study based on track stations. Mammalia 72(1):15-23.

NRC - National Research Council. 1981. Techniques for the Study of Primate Population Ecology. Washington D.C., National Academic Press. 233p.

Paglia, A. P.; Fonseca, G. A. B.; Rylands, A. B.; Herrmann, G.; Aguiar, L. M. S.; Chiarello, A. G.; Leite, Y. R. L.; Costa, L. P.; Siciliano, S.; Kierulff, M. C. M.; Mendes, S. L.; Tavares, V. C.; Mittermeier, R. A. \& Patton, J. L. 2012. Lista Anotada dos Mamíferos do Brasil/ Annotated Checklist of Brazilian Mammals. Occasional Papers in Conservation Biology 6:1-76.

Pardini, R.; Ditt, E. H.; Cullen Jr, L.; Bassi, C. \& Rudran, R. 2006. Levantamento rápido de mamíferos terrestres de médio e grande porte. In: Cullen, Jr. L.; Rudran R. \& Valladares-Pádua, C. eds. Métodos de Estudo em Biologia da Conservação \& Manejo da Vida Silvestre. Curitiba, Editora da Universidade Federal do Paraná. p.181-201.

Peres, C. A. 2000. Effects of subsistence hunting on vertebrate community structure in Amazonian forests. Conservation Biology 14(1):240-253.

2001. Synergistic effects of subsistence hunting and habitat fragmentation on Amazonian forest vertebrates. Conservation Biology 15(6):1490-1504.

Peres, C. A. \& LAKe, I. R. 2003. Extent of nontimber resource extraction in tropical forests: accessibility to game vertebrates by hunters in the Amazon Basin. Conservation Biology 17(2):521-535.

Peres, C. A. \& Palacios, E. 2007. Basin-wide effects of game harvest on vertebrate population densities in Amazonian forests: implications for animal-mediated seed dispersal. Biotropica 39(3):304-315.

REGH, J. A. 2006. Seasonal variation in polyspecific associations among Callimico goeldii, Saguinus labiatus and Saguinus fuscicollis in Acre, Brasil. International Journal Primatology 27(5):1399-1428.

Robinson, J. G. \& Redford, K. H. 1986. Body size, diet and population density of neotropical forest mammals. American Naturalist 128(5):665-680.

Rocha, E. C. \& Dalponte, J. C. 2006. Composição e caracterização da fauna de mamíferos de médio e grande porte em uma pequena reserva de cerrado em Mato Grosso, Brasil. Revista Árvore 30(4):669-678.

Rosas, G. K. C. \& Drumond, P. M. 2007. Caracterização da caça de subsistência em dois seringais localizados no estado do Acre, Amazônia. Embrapa Documentos (109):1-31.

Scoss, M. T.; Marco Junior, P.; Silva, E. \& Martins, S. V. 2004. Uso de parcelas de areia para o monitoramento de impacto de estradas sobre a riqueza de espécies de mamíferos. Revista Árvore 28(1):121-127.

Schipper, J.; Chanson, J. S.; Chiozza, F.; Cox, N. A.; Hoffmann, M.; Katariya, V.; Lamoreux, J.; Rodrigues, A. S. L.; Stuart, S. N.; Temple, H. J.; Baillie, J.; Boitani, L.; Lacher, JR., T. E.; Mittermeier, R. A.; Smith, A. T.; Absolon, D.; Aguiar, J. M.; Amori, G.; Bakkour, N.; Baldi, R.; Berridge, R. J.; Bielby, J.; Black, P. A.; Blanc, J. J.; Brooks, T. M.; Burton, J. A.; Butynski, T. M.; Catullo, G.; Chapman, R.; Cokeliss, Z.; Collen, B.; Conroy, J.; Cooke, J. G.; DA Fonseca, G. A. B.; Derocher, A. E.; Dublin, H. T.; Duckworth, J. W.; Emmons, L.; Emsle, R. H.; Festa-Bianchet, M.; Foster, M.; Foster, S.; Garshelis, D. L.; Gates, C.; Gimenez-Dixon, M.; Gonzalez, S.; Gonzalez-Maya, J. F.; Good, T. C.; Hammerson, G.; Hammond, P. S.; Happold, D.; Happold, M.; Hare, J.; Harris, R. B.; Hawkins, C. E.; Haywood, M.; Heaney, L. R.; Hedges, S.; Helgen, K. M.; HiltonTaylor, C.; Hussain, S. A.; Ishit, N.; JefFerson, T. A.; Jenkins, R. K. B.; Johnston, C. H.; Keith, M.; Kingdon, J.; Knox, D. H.; Kovacs, K. M.; Langhammer, P.; Leus, K.; Lewison, R.; Lichtenstein, G.; Lowry, L. F.; Macavoy, Z.; Mace, G. M.; Mallon, D. P.; Masi, M.; McKnight, M. W.; Medellín, R. A.; Medici, P.; Mills, G.; Moehlman, P. D.; Molur, S.; Mora, A.; Nowell, K.; OAtes, J. F.; Olech, W.; Oliver, W.R.L; Oprea, M.; Patterson, B. D.; Perrin, W. F.; B. A. Polidoro, W. R. L.; Pollock, C.; Powel, A.; Protas, Y. V.; Racey, P.; Ragle, J.; Ramani, P.; Rathbun, G.; Reeves, R. R.; Reilly, S. 
B.; Reynolds III, J. E.; Rondinini, C.; Rosell-Ambal, R. G.; Rulli, M.; Rylands, A. B.; Savini, S.; Schank, C. J.; Sechrest, W.; SelfSullivan, C.; Shoemaker, A.; Sillero-Zubiri, C.; De Silva, N.; Smith, D. E.; Srinivasulu, C.; Stephenson, P. J.; Strien, N. V.; Talukdar, B. K.; TAYlor, B. L.; Timmins, R.; TiRira, D. G.; Tognelli, M. F.; Tsytsulina, K.; Veiga, L. M.; Jean-Christophe Vié, Williamson, E. A.; Wyatt, S. A.; XIE, Y.; Young. B. E. 2008. The status of the world's land and marine mammals: diversity, threat, and knowledge. Science 322:225-230.

Silveira, M. 2005. A Floresta aberta com bambu no sudoeste da Amazônia: padrões e processos em múltiplas escalas. Rio Branco, Editora da Universidade Federal do Acre. 153p.

Simonnetti, J. A. \& Huereco, I. 1999. Uso de huellas para estimar diversidade y abundancia relativa de los mamíferos de la reserva de la biosfera - Estacion Biológica del Beni, Bolivia. Mastozoologia Neotropical 6(1):139-144.

STANDER, P. E. 1997. Tracking and interpretation of spoor: scientifically sound method in ecology. Journal of Zoology 242:329-341.

StATSOFT. 2004. Statistica (data analysis software system). Statsoft Inc., version 7. Available <www.statsoft.com>. Accessed on 17 May 2012.
Terborgh, J.; Lopez, L.; Nuñez, P.; Rao, M.; Shahabuddin, G.; Orihuela, G.; Riveros, M.; Ascanio, R.; Adler, G. H.; LAMBert, T. D. \& Balbas, L. 2001. Ecological meltdown in predator-free forest fragments. Science 294:1923-1926.

Turner, I. M. \& Corlett, R. T. 1996. The conservation value of small, isolated fragments of lowland tropical rain forest. Trends in Ecology and Evolution 11(8):330-333.

Vianna, V. M. \& Pinheiro, L. A. F. V. 1998. Conservação da biodiversidade em fragmentos florestais. Série Técnica IPEF 12(32):25-42.

Voss, R. S. \& Emmons, L. H. 1996. Mammalian diversity in Neotropical lowland rainforests: a preliminary assessment. Bulletin of the American Museum of Natural History 230:1-115.

Wright, S. J.; Gompper, M. E. \& DeLeon, B. 1994. Are large predators keystone species in Neotropical forests? The evidence from Barro Colorado Island. Oikos 71(2):279-294.

Wright, S. J.; Stoner, K. E.; Beckman, N.; Corlett, R. T.; Dirzo, R.; Muller-Laundau, H. C.; Nuñez-Iturri, G.; Peres, C. A. \& Wang, B. C. 2007. The plight of large animals in tropical forests and the consequences for plant regenerations. Biotropica 39(3):289-291. 